\title{
Joan Miró: pequena semiótica do excremento*
}

*Com o título de "Idea y matéria en Joan Miró. Pequeña semiótica del excremento", este trabalho foi primeiramente publicado em Praxis Filosófica, 7 (1997, Cali) e, posteriormente, em Manía, 2 (1998, Barcelona). Para sua versão ao português, o trabalho passou por uma revisão e foram feitas algumas alterações.

Tradução: Eduardo Peñuela Cañizal

Pere Salabert Universidade de Barcelona/Espanha 


\section{Resumen}

Este ensayo no trata de las pinturas de Joan Miró - algunas de las cuales no obstante comentaré -, sino su método de creación de acuerdo con las palabras del propio Miró: primero durante su colaboración con el grupo teatral La claca (1974) para la obra Mori el Merma (1974) a partir de Ubu rey, la obra maestra de Afred Jarry; segundo cuando con ocasión de una larga entrevista con Georges Raillard (Ceci est la couleur de mes rêves, Paris, 1977) el artista declara que una pintura considerada por Raillard como un ejemplo inusual pero interesante de cromatismo es una muestra de excremento. En relación pues con este extremo, el hilo conductor de las páginas que seguirán será el excremento en el quehacer mironiano.

\section{Palavras-chave}

Miró, excremento, imagem pictórica, estética, cultura

\section{Abstract}

This essay does not strictly concern the works of the Catalan painter Joan Miró - although some of them are commented -, but his method of creating, as stated by Miró's own words: first, when he cooperates with the theatrical group La claca in Mori el Merma (1974), a play after $U b u$ roi, the masterpiece of Alfred Jarry; and second when the artist, holding a long conversation with Georges Raillard (Ceci est la couleur de mes rêves, Paris, 1977) declares about a «painting» that Raillard finds out, and looks upon as an example of an unusual but interesting color, that is an excrementitious sample. So related to this subject the run of the discourse will be the significance of excrement in the way Miró worked.

Key words

Miró, excrement, pictorical image, aesthetics, culture 
La mierda no ha cesado nunca de mantener, incluso en el ateísmo más declarado, una extraña y fascinante proximidad con Dios. De la mierda no se habla. Pero ningún objeto, ni siquiera el sexo, ha dado tanto que hablar. D. Laporte, Histoire de la merde, 1978.

\section{Observações prévias: história e mito}

7 udo quanto nos concerne coletivamente está atrelado ao mito: a natureza, a vida e a morte, a arte, a ciência e a religião. A 1 figura do artista não escapa desse princípio. Uma vez mitificada, sua obra e personalidade se fixam nos recintos de um espaço mental que, dificilmente, consegue ver seu objeto em razão do manto com que a admiração termina encobrindo-o. Se, de um lado, os mitos antigos, ao negar o tempo cósmico, proclamam sua indefinida duração cultural, de outro, os mitos modernos adotam uma posição inversa: eles se opõem à continuidade temporal através de formas culturais de curta duração, formas, portanto, transitórias. Nos primeiros, predomina a pura inércia, ao passo que, nos segundos, reina um movimento alimentado pelas mudanças. Portanto, naqueles, o que conta é a eternidade e, nestes, a fugacidade. A mesma diferença que Bergson observara entre a inteligência e a razão: na primeira, a instabilidade e, na segunda, o deslocamento. Disso resulta que nossos mitos, preferencialmente intuitivos, se enclausurem nos limites estreitos das modas culturais. Mesmo assim, sua função, com mais ou menos eficácia, é regular na ordem social. De maneira que, sob o aspecto ideológico, um mito, em nossos dias, coloca no lugar da opinião pessoal um estado geral de opinião: na dimensão pragmática, 
permite a ação sem pensamento e, na estética, resolve a necessária educação do bom gosto com uma degustação massificada pelos conselhos da publicidade.

Na medida em que a história ainda é concebida mais como um progresso do que como um processo, também ela possui uma natureza mítica. Ao final de contas, é a estrutura temporal dos mitos a força que repele a historicidade. Pouco importa que sejam antigos ou modernos, de tempo longo ou curto, pois, no fundo, sua particular temporalidade supõe uma duração sem evolução. Os mitos antigos aparecem no horizonte cultural, aí eles se mantêm ou desaparecem, e se não mudassem é porque deixariam de ser funcionalmente mitos para entrar no domínio da imaginação poética ou no do hábito social. Por isso, não sendo ocupado o lugar vacante por um novo mito, a função suspensa do primeiro passa a ser substituída por um tópico ideológico ou por uma prática rotineira.

Alongar-me-ei um pouco sobre esta última questão porque, dessa maneira, podemos ficar mais perto de um modelo moderno de mito, de um modelo que corresponde a um tópos cultural caso não pertença à moda diretamente. Essa é a razão de que, num período histórico determinado e numa dada comunidade, existam diferenças entre mitos, rotinas (hábitos rotineiros) e tópicos. Em síntese, se a função reguladora do mito consiste em acompanhar a ação social com um arrazoado argumentativo - o que não significa que tal arrazoado seja crível racionalmente -, a rotina coletiva é um comportamento ou uma ação recorrente alheia a qualquer argumentação que possa afetá-la em sua estrutura. No concernente ao tópico, constitui uma idéia, um conceito isolado ou, inclusive, uma argumentação completa, mas fechada e sem nenhuma relação necessária com comportamentos ou ações. Rotinas e tópicos ideológicos possuem em comum a tendência a perseverar sem se alterar. Nascem e se formam à maneiras dos mitos e morrem, mas não mudam.

É claro que essa comum reação à historicidade nem sempre os coloca à margem da história. Ao contrário, costumam fazer parte dela, já que eles, no domínio do histórico, assumem a condição de reguladores temporais integrando, em maior ou menor escala, as diversas correntes de que a própria história se alimenta. Compreende-se, assim, 
que um mito não tenha história: é um relato, uma idéia - ou, mesmo, um slogan - que determina o pensamento ou a atividade social. Em contrapartida, parece cada vez mais evidente que a História constitui um mito ao avesso. A atividade humana não encontra em seu próprio seio nenhuma formulação prévia em forma de narração (exceto se concebemos a tradição como um modelo linear que é necessário seguir), posto que é a narração que provém da atividade. Isto nem sequer significa que as ações se adiantem às idéias e determinem seu conteúdo. Não, pois é disso que a historiografia se ocupa propiciandolhe a forma de uma memória coletiva fascinada pela realidade. Ao fim e ao cabo, se o mito não tem história, a História é um universo de mitos, desde narrações ideológicas a modas culturais. E, logicamente, contém automatismos sociais, ora estes surjam espontaneamente, ora resultem do desaparecimento de modas e ideologias.

Nesse sentido, ao fazermos história - e estou me referindo à história da arte -, podemos, ao menos, lidar com duas coisas. Primeiro, tratamos de estabelecer relações de conformidade ou desconformidade entre propósitos ou ações (documentos e fatos), entre propósitos diferentes ou entre ações diferentes e separadas no tempo. Depois procuramos alguma lei de parentesco entre fenômenos culturais contemporâneos. Contudo, essas duas operações podem ser simultâneas, mas enquanto a primeira delas corresponde à ordem diacrônica, a segunda se ocupa de sincronias. Assim, por exemplo, podemos buscar os propósitos estéticos contidos na obra pictórica de Leonardo da Vinci, intentando, com isso, detectar suas possíveis influências em outros artistas posteriores (digamos, nos maneiristas italianos do século XVI, na pintura espanhola do século XVII), ou bem, tratar de ver sua própria obra como uma tentativa de resolver os problemas contidos no pensamento teórico vinciano que conservamos em seus escritos. Também é possível rastrear até que ponto Molière responde, no século XVII, à influência formal da comédia italiana do século anterior ou é capaz de se manter relativamente independente da ditadura estética da Academia. Tome-se tudo isso apenas como um exemplo, porque, de qualquer modo, não é nossa intenção, neste trabalho, ir tão longe: limitar-nos-emos a cotejar 
certas declarações de Miró acrescentando-lhes alguns exemplos de sua obra plástica com a finalidade de demonstrar que seu afazer criativo - embora tenha algum parentesco com outros criadores de seu tempo - segue uma direção particular contrária à traçada por uma reflexão estética que, em muitos momentos, se aproxima muito do mito e não menos da rotina. Para tanto, convém, porém, fazer algumas observações prévias: umas de natureza estética e outras de cunho metodológico.

\section{A "idéia" e a sensação}

As reflexões feitas acima servem para nos pôr em estado de alerta frente a certos mitos, tópicos ou rotinas contidos na história da arte. Por outro lado, mesmo fazendo referência a uma dupla via metodológica no que diz respeito à obra de Miró, não será nossa pretensão, evidentemente, extrair dela todas as suas conseqüências. Limitar-nos-emos a fazer algumas indicações, tendo a esperança de que sejam suficientes para centrar minha atenção, em duas ou três declarações documentadas do próprio artista, com o intuito de relacioná-las entre si na expectativa de compreendê-las, levando em conta, de um lado, a sincronia no contexto da arte contemporânea e, de outro, a diacronia enquanto produto de uma tradição que o próprio artista nega com sua obra.

Utilizaremos um exemplo literário para, em continuação, generalizar. Eckermann, interlocutor de Goethe, confiado na crença de que uma idéia diretriz determinaria uma obra de arte, perguntou ao poeta qual a "idéia" que ele quis expressar ao escrever seu Tasso. Goethe respondeu, com circunspeção, que nenhuma. $O$ poeta não tinha nenhuma idéia que comunicar. $\mathrm{E}$, se por acaso isso não ficou bastante claro, acrescentou que, na origem da obra poética, há sensações, impressões, intuições...mas não idéias. A poesia alcança seu ápice no instante em que se torna menos produtiva para a inteligência, disse. Entenda-se que "idéia" significa aqui algo mais do que imagem ou representação mental. É, sem dúvida, uma intenção consciente, talvez um esquema, sempre, porém, algo conceitual que quando aplicado à tarefa criativa conduz essa tarefa no rumo do concreto.

Significação $20 \cdot 158$ 
Posto isso, cabe perguntar-se, em primeiro lugar: por que uma parte da crítica moderna aplica ainda a Miró - às vezes de modo corriqueiro - esse tópico de origem neoplatônica que, no trabalho do artista, via a resposta expressiva atrelada a uma "idéia prévia" e, depois, a uma intenção consciente de sentido? E, em segundo lugar: que existe efetivamente dessa ou de qualquer outra "idéia" na obra de Miró quando passamos a julgá-la a partir das suas próprias declarações - intenções, propósitos, explicações documentadas sobre sua maneira de atuar no trabalho, etc -? De fato, o conceito de idéia prévia tem uma origem filosófica, logo se converte num mito estético e, uma vez vazio de conteúdo, fica sendo em tópico cultural. Hoje nos é oferecido como uma explicação que serve para repetir o que já acreditamos saber acerca de obras que, com frequiência, procedem de uma ação criativa cuja direção é contrária ao argumento empregado para explicá-las.

Em outras palavras: em que se apóia a obra mironiana, numa técnica submetida ao controle do logos ou procedente da empeiria? É a produção deste artista obra de prática ou de raciocínio? Neste ponto, as coisas participam do mito do conteúdo e se aferram ao tópico da "mensagem" entendida como produto dum logos intencional? Não é suficiente lidar com uma arte que se engendra na vontade ou no querer-fazer. Além disso exigimos dela um logos, uma razão diretriz. Almejamos que se engendre num saber-fazer capaz de nos assegurar a melhor via para uma tarefa semântica da obra. $\mathrm{O}$ termo "expressão", usado tão amiúde pela crítica, apresenta esse duplo valor modal. No trabalho criativo, o querer-fazer tem de ser um saber-fazer semioticamente realizável numa linguagem "com conteúdo" De ser assim, a tarefa acabada do artista constituirá a realização expressiva de uma "idéia" que nós, enquanto receptores, a assumiremos como mensagem. A explicação não pode ser mais evidente. Diante de uma obra inacabada que apresenta uma bela matéria ocre de textura erodida, também Raillard - e com isso antecipo o núcleo destas páginas - perguntou a Miró se haveria outras obras como essa, se a "intenção" do artista era produzir uma série em concordância com alguma "idéia"...E Miró simplesmente respondeu que essa bela matéria a obteve defecando. Nem mais nem 
menos. Com efeito, como dizia Goethe, na origem da obra há intuições, sensações, impressões, quando menos impulsos...e deposições.

Porque teria de ser a pintura tão diferente da poesia, sobretudo quando pensamos numa arte contemporânea que parece ter assimilado aquela observação romântica de Goethe até suas últimas conseqüências? Não ocorrerá isso pelo fato de seguirmos dando o nome de "idéias" a um impulso simples e suficiente? Onde fica a idéia ou intenção num dripping de Pollock, numa composição de John Cage? A não ser na vontade de excluir toda reflexão ou idéia previa, qualquer intenção consciente, onde, no automatismo surrealista fica, pois, a idéia?

\section{Analisar e interpretar: que mais dizer?}

O trabalho de Joan Miró, como o de qualquer artista, possui certos traços que o caracterizam. E para objetivá-los são necessárias várias tentativas. Mas dado que tais tentativas supõem, em seu conjunto, uma atividade analítica aplicável a qualquer artista, é possível dizer, generalizando, que a crítica classifica uma obra em sua globalidade segundo diretrizes de "gênero" - pintura e desenho, gra-

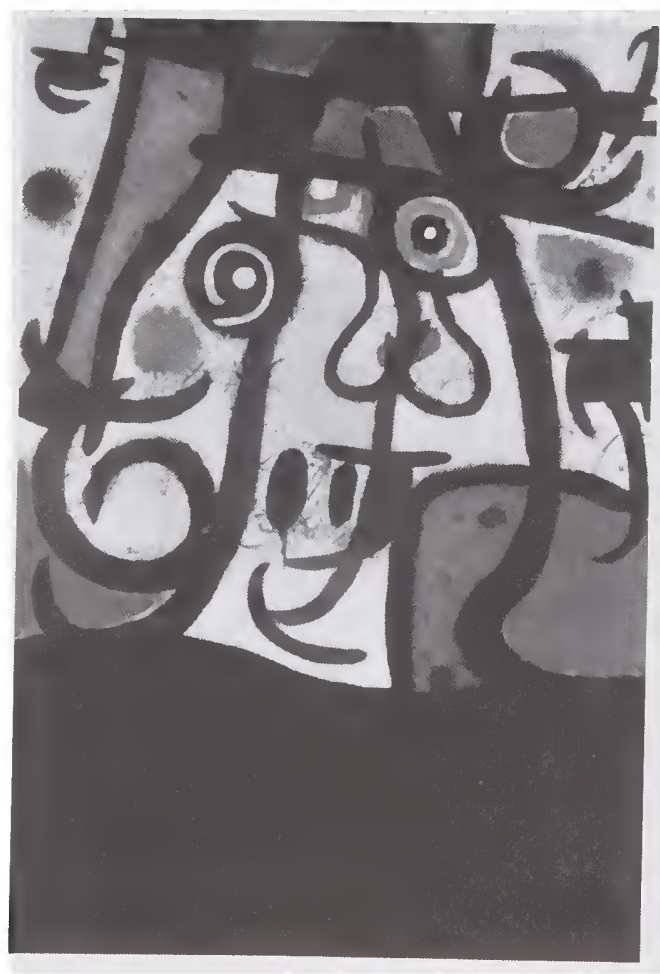
vura, escultura, obra cerâmica e teatro, por exemplo - para, depois, ordená-la cronologicamente. Isso seria um primeiro passo, o que nos permite, mediante o estudo comparativo de morfologias e materiais, confrontar a temporalidade da produção com as variações em suas diferentes ocorrências. Daí surge uma trajetória ideal que costuma receber o nome de evolução pessoal. É um esquema temporal que, ao nos dar um ponto de vista dinâmico da obra, também coloca à nossa disposição a possibilidade de detectar nela uma espécie de lógica interna.

$\overline{\text { Significação } 20 \bullet 160}$ 
Extraímos, então, uma primeira compreensão da obra. Claro que, em contrapartida, teremos deixado a obra num estado de isolamento que somente será justificável por essa dinâmica internar.

Para sair dessa armadilha será necessário, no entanto, um último ato, o mais importante: uma contextualização que passando pela análise morfossintática possa adentrar-se na virtualidade do conteúdo. Dito de outra maneira. Detectamos, primeiro, tipologias formais e, ao mesmo tempo em que identificamos recorrências figurativas, vemos o grau de iconicidade. Depois, localizamos em tudo isso funções simbólicas que, segundo a convenção, privada ou compartida, a que estejam submetidas, serão mais ou menos explicitadas. A lógica que tínhamos encontrado entrará agora a formar parte de um tecido muito mais extenso em que a personalidade do artista ganhará relevo ou, contrariamente, tenderá a dissolver-se no conjunto. Ou seja, o "estilo" pessoal se destacará (ou não) no contexto muito mais geral de um estilo global.

No final de contas, quando seguimos uma via orientada pelo raciocínio (outra coisa é o imediatismo da experiência receptiva, que valoriza previamente a reflexão), determinamos a validade estética de uma obra em função das diferenças, desvios ou contrastes que apresenta no atinente ao contexto cultural do qual faz parte, identificando com isso a especificidade do autor ou - para empregar o termo romântico que lhe corresponde - sua "originalidade"

Diante, porém, de uma produção extensa é difícil, para não dizer impossível, recorrer apropriadamente a todas as etapas do processo analítico, pois a operação crítica costuma limitar-se a alguma delas: identifica, data, analisa ou avalia. Ou talvez faça tudo isso bem seja através do caminho que se acaba de assinalar ou de outro parecido -, mas centrando-se numa obra, num curto trecho ou numa amostra que aparecerá como corpus representativo do conjunto... visto que tal processo, em sua totalidade, não deve ser procurado no estudo em particular, mesmo que este seja denso. Se assim fosse, todo o dizível acerca da obra de Miró - ou acerca da obra de Picasso ou de qualquer outro artista medianamente fértil - estaria na soma total das contribuições que tiveram, têm ou terão os artistas como seu objetivo. Vale dizer, quando nos referimos a terão, que para a 
análise formal pode haver um limite, mas não para a interpretação de uma obra de arte - salvo se aquele que interpreta leva em conta no seu trabalho em certo sentido comum transformado em guia para a pertinência. É claro que, neste caso, aparecerão limites. Mas, como se limitar na interpretação ao sentido comum quando a própria obra - na arte moderna, ao menos - é habitualmente um exemplo de um desvio de sentido? Assim, a análise formal pode ter um limite, mas ele desaparece inevitavelmente no instante em que a interpretamos.

Há, contudo, artistas de cuja obra tem-se falado tanto que acrescentar ao já dito alguma coisa relativamente nova parece, incluso, temerário, embora a temeridade não dependa de que se tenha dito tudo quanto se podia ou devia dizer. Depende, isso sim, de outros fatores. A saber: que o dito tenha-se convertido em couraça, tenha-se tornado uma defesa argumentativa que dificulta, ou pelo menos condiciona, qualquer intenção de aceder à obra sem muitos preconceitos. Quando isso ocorre, o artista já entrou na categoria do mito cultural e sua obra, transformada em fetiche, não admite crítica. Somente a justificação vinda das atitudes admirativas. Que se pode dizer ainda hoje de Miró que não seja uma variação interpretativa de outra variação anterior, numa interminável concatenação de metalinguagens? E, sobretudo, como dizer abertamente o que pode haver numa obra que seja contrário às leis do "bom gosto" ou aos princípios tácitos de pertinência semântica num âmbito cultural dado como o nosso? Com isso, já estou me referindo à merda na obra de Miró. Mas vejamos, antes, alguma outra coisa.

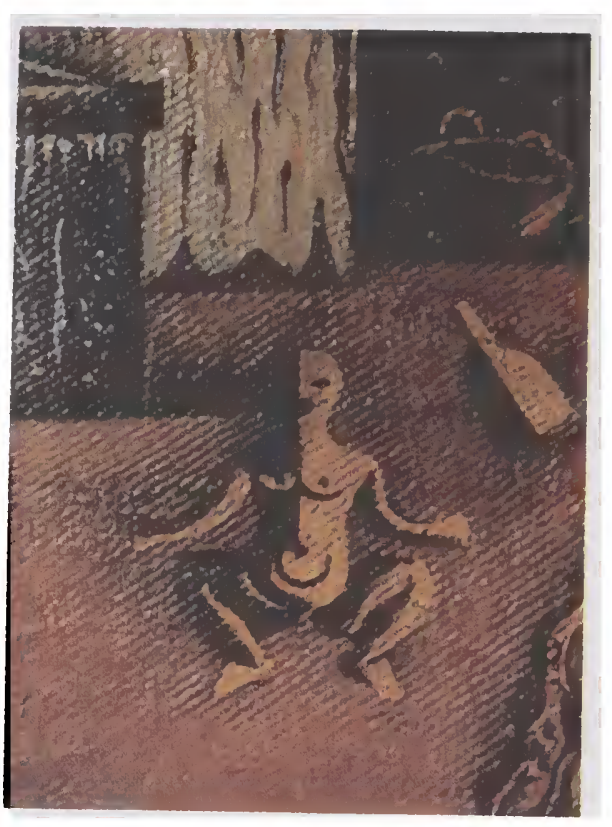

\section{Idéia ou impulso: a matéria sugestiva}

Disse, mais acima, que o mito da "idéia", de procedência neoplatônica e logo convertido em visão intuitiva, se mantém vigente 
em torno da arte com variações, insuficientes, em todo caso, para destruí-lo. Em sua mente, o artista possui uma "idéia" que deve atravessar a matéria trabalhando com as mãos. Mas como nesse trabalho, mais do que em qualquer outro, existe uma certa fatalidade proveniente do fato de que a matéria, com sua habitual inércia, resiste a qualquer mudança (referindo-se a ela, Dante dizias que era "surda") e, em decorrência disso, surge a seguinte questão: conseguirá o artista dominar a matéria, poderá "enganá-la conferindo-lhe a forma correspondente a sua idéia? Ser um verdadeiro artífice dependerá da capacidade que cada um tenha de sair vitorioso de tal empreendimento. Desde Plotino até Hegel pelo menos, o mito do trabalho artístico tem sido esse. E não deixa de ser curioso que com esses ou outros termos parecidos, ainda continua sendo esse. A matéria, uma vez formada, traz como resultado a "união feliz" da forma e do conteúdo - união, dito seja de passagem, que sugeria a Lacan histórias de ordem sexual - . Pois bem, um amplo setor da crítica contemporânea tem aplicado este esquema prévio ao trabalho mironiano, inclusive sem constrangimento diante das reiteradas declarações do próprio artista no que diz respeito a um "impulso" que funcionava como principal fator desencadeante de seu trabalho. E, embora no final do século XIX, a psicologia já tinha concebido duas grandes modalidades para a imaginação criativa, a intelectual que atua através da reflexão e a intuitiva (T. Ribot), uma das posições dominantes era a de que a invenção dimana sempre de acordo com uma ordem que vai da abstração à concreção (Paulhan), ou do esquema - segundo afirmava Bergson - à imagem, isto é: da unidade conceitual à percepção por partes.

Convém observar, entretanto, que na atividade criativa do Miró maduro não há indícios de nenhuma idéia prévia que busque uma matéria ad hoc para configurar-se. Não é o conceito o que requer a percepção. O que existe é unicamente uma percepção concreta que conduz à outra, e esta à seguinte, numa concatenação cujo final constitui uma rede de sentido e coincide com uma obra, $\mathrm{Na}$ origem da ação mironiana estão a terra e os signos da degradação material ou, dizendo-o de outra maneira, a imagem sem o esquema.

$\overline{\text { Significação } 20 \cdot 163}$ 
Com a esperança de não ser mal entendido, atrevo-me a dizer, resumindo, que Miró "não tem idéia". É por isso que parte das texturas, manchas, salpicamentos, objetos e materiais de refugo, ferro oxidado, coisas carcomidas, desgastadas etc. Jogado sobre a tela, inclusive o liquido dissolvente que remanesce depois de limpar os pincéis sugere - segundo uma atitude parecida à de Max Ernst formações minerais e arborescências. $E$ fala muito pouco (em realidade, nada) de idéias, digamos, de intenções, de esquemas mentais, projetos ou programas. Quando lhe perguntam - como Eckermann a Goethe - o que faz antes de começar uma obra, sua resposta inclui termos como "força" "impulso", e, depois, enigmaticamente, introduz uma exclamação: "clac!" Clac!? Será a onomatopéia de algum choque, o ruído de uma queda? Ou é esse "Entendi!" do sujeito que, de repente, intui o que algum resíduo de coisa, algum material roído sugere que poderia fazer com ele? Caso seja isso, então o processo criativo já ficou invertido. Não é a reflexão que desemboca na prova concreta do processo, é a prova material que conduz à outra prova, e assim sucessivamente, para que, no fim, seja o receptor - é dizer, nós os espectadores - quem reflita e interprete.

O artista, mesmo não impondo idéia alguma, interroga com o olhar certos materiais - uma lata de conservas oxidada, um pedaço de corda, um calhau da praia: quase nada. À procura do temo do desgaste e degradação, percorre com a vista a superfície textual e, repentinamente, a lata, a corda e o calhau falam. "Clac!, pronto: colocá-lo-ei aqui, dando-lhe um toque de cor e..." Assim fala Miró.

O que ocorre, no entanto, é que um mito dá lugar a outro. Melhor dizendo, a realidade trata de anular os mitos tornando-se, por sua vez, mito. Por isso, o real - que o artista provavelmente busca nunca está lá onde parece falar, senão nesses intervalos nos quais nada resta para ser dito. Tal como o expressava Michelangelo, já sabemos que a idéia deve ser prévia e a mão tem de servir ao intelecto que a guia. Assim, da reflexão nasce o ato que, à procura da idéia, conduz a mão no trabalho... Hoje é dessa maneira. A psicologia, a trazer a idéia do céu até a terra, falará do projeto, mais da intenção possivelmente, consciente desde cedo. No tocante à semiótica (Greimas), a preferência radica em ampliar essa intenção 
com a impulsividade prévia a um estado normal consciente e, tendo em mira isso, adota o termo intencionalidade. Aqui a "idéia" clássica se humaniza totalmente devido a que a intenção, ao incluir uma parte de impulso, tolera a inconsciência na ação.

\section{O "clac!"' o espírito e a matéria}

Pensando bem, não se referirá aquele "clac!" na ordem subjetiva a uma fratura produtiva no fio contínuo da consciência? Será, portanto, um ponto catastrófico: sinal de mudança, baixada ou subida de tensão, alteração direcional, queda. Mais nada. Porque se observamos com atenção não é fácil detectar nos procedimentos de Miró uma emergência espiritual destinada à transfiguração de matéria alguma. Ao contrário, o que ocorre - trataremos melhor desse assunto mais adiante - é uma espécie de renúncia a considerar as coisas, os objetos materiais levando em conta o que significam: ao contrário, adota-se uma atitude contemplativa em que os objetos se assumem em função daquilo que eles são: coisas. Há, pois, adesão à terra - ora como lugar físico onde pôr os pés, ora como território psicológico -; um interesse puramente material que ganha forma através da ação e se transfigura com o anúncio de algum conteúdo virtual. Nesta ocasião, não nos interessa se essa ação é um trabalho de produção ou um gesto seletivo ao estilo de Duchamp, se consiste em fazer uma escultura, em recolher uma raiz semipodre na orla de uma praia ou em nos apresentar uma cadeira desmantelada como sendo uma obra de arte. Aquilo que realmente nos importa é que de maneira semelhante à boa parte da arte contemporânea, em Miró existe uma linguagem anterior à linguagem natural, que o afazer artístico é sempre um antecedente no que diz respeito ao mundo, que a ação é prévia a qualquer idéia. E que, em definitivo, a forma de uma matéria qualquer - que ao que parece possui suas próprias idéias se sabemos escutá-las - vem antes do que o conteúdo (mesmo supondo que algum conteúdo nos chegue).

Quando Miró insiste em dizer que sua mão o surpreende mais do que qualquer outra coisa, cabe perguntar-se: que quer dar a entender com isso? Que será o que quer dizer quando afirma que ao 
começar uma obra toda a sua atenção se concentra no começo? De que começo fala? Evidentemente, não de idéias ou conceitos, mas de um "clac!". Alude a um magnetismo, a uma força procedente de alguma mudança tensiva gerada por algum contato com a matéria. Refere-se, enfim, a um querer-fazer que independentemente do saber-fazer já é assumido como um dever-fazer.

Como certa técnica surrealista, como o expressionismo abstrato que veio depois (Pollock) ou o gestualismo, o caso de Miró difere, no sentido de que se opõe, do que a estética da arte conta ao longo da história. O que Michelangelo dizia acerca da idéia é necessário equacioná-lo ao avesso. Qual é agora a força desencadeante? Um choque sensível: "clac!". Que Goethe se sentia motivado por uma sensação, por uma impressão? Também Miró. Somente que artista catalão releva, na experiência, a importância, podemos chamála de objetiva, de uma matéria impressionante. E essa matéria, que é a Matéria por antonomásia, equivale a quê, não já em nossa consciência cultural, senão em nosso subconsciente grudado na terra? Melhor dizendo: em última instância, a Matéria não é o excremento?

Precisamente disso se trata. A merda é a Matéria por definição. O único problema é que dela - como diz Laporte - nunca se fala: seria exceder-se, cair no mau gosto. Também não é correto tocar nesse assunto. Nossa cultura do "não tocar" atinge os dois extremos: proibido tocar tanto o que desejamos muito (porque esse ato suja ou desgasta) quanto o que desprezamos (porque nos contamina). Ao final de contas, numa criação divina fortalecida pelo desejo humano de beleza e perfeição simbólicas, o excremento não tem cabida, permanece extramuros. A merda lembra nossa origem mítica nas trevas. E, no entanto, embora num universo perfeito isso não deva ter lugar, a própria circularidade dessa perfeição leibniziana já nos avisa que o princípio e o fim coincidem nalgum lugar: aquele em que o Espírito por antonomásia - Deus - também é a Matéria: a merda. Objetivamente,

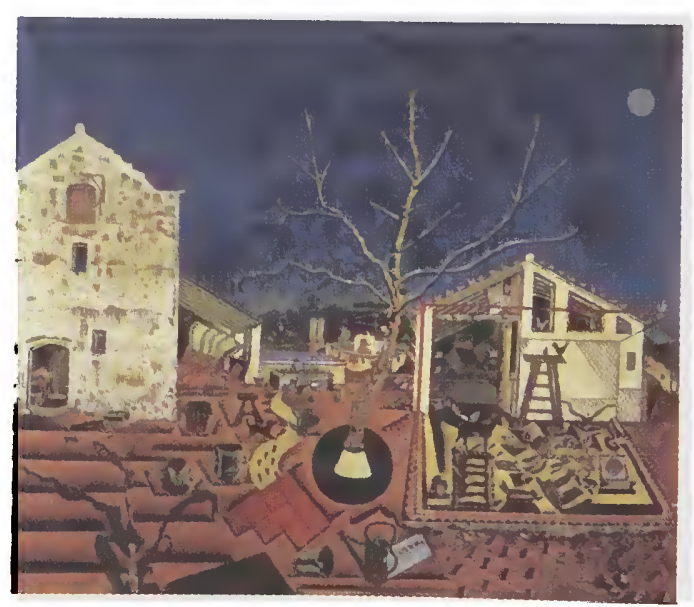


agora, o clac! Mironiano é esse ponto catastrófico em que dois extremos opostos se encontraram.

\section{Repensar as coisas}

Mais uma vez, é Goethe quem dizia que todo o discreto tem sido já pensado..., mas para acrescentar que podemos pensá-lo novamente. Será conveniente revisar a obra de Miró para ver se deixamos algo esquecido no caminho? Tanto do ponto de vista analítico quanto do estético, certamente existem ainda coisas para ver. Se não fosse assim, a obra estaria morta. Claro que insistir nela nos leva a prolongar neuroticamente aquele processo analítico já mencionado neste trabalho. E, dessa maneira, cairíamos na rotina historiográfica. É sempre enriquecedor, porém, voltar a ver uma coisa, sobretudo se se trata de arte, porque a ocasião renova o olhar. Mas uma coisa é olhar e outra pensar. Voltar a pensar Miró pode consistir em continuar indefinidamente as explicações que dele fez um pensamento que, seguindo o caminho da continuidade, já se converteu, talvez, em algo institucional e, em virtude disso, num cacoete cultural. De fato, se tornar a ver uma coisa pressupõe uma mudança do ponto de vistas temporal, repensar ou voltar a pensar é pensar a mesma coisa de outro modo ou segundo outra perspectiva. Vejamos como ocorre.

\section{A merda e o assassinato da pintura, com um prelúdio para o leitor}

Uma vez neste ponto, o leitor fará bem em se decidir pela ironia que a mencionada merda tenha-lhe sugerido ou por ficar com sua opinião - que suponho seja contrária à neutralidade cultural do excremento - abandonando a leitura. Se o leitor pensa que falar de arte e mencionar o excremento não é, de modo algum, assunto sério, que o deixe, pois está em tempo, já que a partir de agora haverá mais merda ainda. Nela nos centraremos com o intuito de classificá-la. E o que virá a seguir pode ser que lhe pareça um texto "doloroso", principalmente se, alternadamente, tira desta palavra ou coloca nela 
a primeira letra, fazendo com que, nalgum momento, fique o termo "oloroso"... É claro que o leitor também pode ver isso de maneira realista. Basta opinar, por exemplo, que mesmo sendo a merda uma substância inabitual, incomum num discurso minimamente sério, essa sua raridade discursiva depende unicamente de uma pose cultural. Uma pose que perpetua aquele velho mito estético segundo o qual a arte e a beleza sempre andam juntas e, em razão de que a beleza não deve cheirar...., a arte também deve ser insípida, embora provoque em nós o gosto. O que - e isso temos de aceita-lo - é uma solene bobagem. O leitor que pense assim - imaginando que exista algum pode achar que a atitude social de recusa diante da merda não depende de uma verdadeira condição digamos excêntrica dessa matéria (essa particularidade a coloca nas antípodas das formas belas e do "bom gosto"), ressaltando serem a beleza e o gosto imprescindíveis para falar da arte. Ao contrário: o excremento só é excedente devido à recusa cultural que lhe é anterior e que tem objetivado nele. Se algum leitor pensa deste modo, pode continuar a leitura, pois essa atitude significará que está em condições de reconhecer que nada, nem mesmo o nariz mais delicado, nem a convencional satisfação do gosto, nos obriga a excluir a merda - pelo menos literariamente! - do horizonte das coisas dignas de ser pensadas.

Se for possível falar da matéria fecal sem exercer profissão de psicanalista, especialmente quando nos reportamos à arte, a verdade é que direta ou indiretamente tem sido objeto de um singularíssimo afeto por parte de alguns artistas, Rembrant ou Toulouse-Lautrec, Michelet ou Jean Genet. E acrescentarei que tal afeto, particularmente forte no caso de Miró, se estende - como veremos - à urina. Merda ou urina? Deveria estar com a razão Jean Cassou quando, no ano de 1962, dizia que à medida que sua obra se enriquecia e seu talento

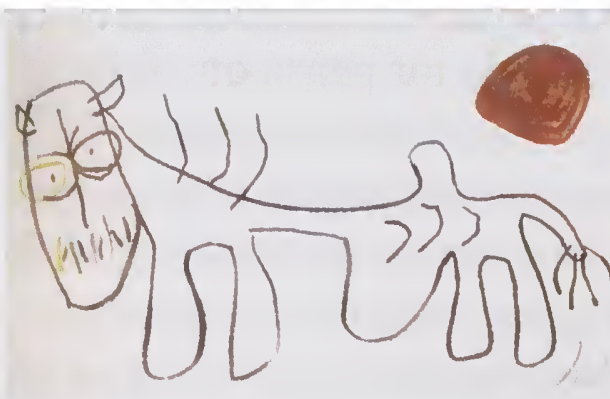
aumentava, Miró se tornava pessoalmente mais ingênuo. Aqui a teoria psicanalista parece se impor. Ingenuidade infantil relacionada com a curiosidade pelo excremento? Fixação numa fase anal acompanhada pela mania de ordem e limpeza?

$\overline{\text { Significação } 20 \bullet 168}$ 
Talvez. Mas o que me preocupa neste caso não é uma possível regressão do indivíduo maduro à infância, mas tão somente aquilo que parece desprender-se deste fenômeno com relação à pintura.

Num livro dedicado a Miró, Georges Raillard (1978) transcreve uma série de conversas das quais, já faz alguns anos, me chamou a atenção alguma das observações do artista $^{1}$ Do que lá se dizia, várias coisas resultam curiosas. E alguma delas particularmente inquietante. Refiro-me àquela, já mencionada de passagem, surgida quando Miró diz a Raillard que sua própria mão o surpreende. O que é que o surpreende: a mão ou a ação que ela, fora de seu controle, realiza? É o que tem sido chamado de "automatismo psíquico" manifesto no ato aleatório? Ou será que se trata de alguma surpresa mais contemplativa? Talvez deveríamos relacioná-lo com a admiração de Paul Valéry (1941, p. 111) quando afirma que sente um estupor filosófico olhando para a sua própria mão sobre a mesa: "estou e não estou nessa mão. Ela é eu e não-eu" "Minha mão", dizemos. E com isso relevamos a propriedade de uma parte anatômica nossa que percebemos segundo uma suposta autonomia que nos apresenta essa mão como algo alheio. Será um outro Miró quem corresponde à mão que pinta por Miró? Isso que Miró admira não será, por acaso, um não-eu antimironiano?

Outra daquelas observações se dá quando o interlocutor pergunta curioso pela cor de uma obra inacabada. Sabemos que Miró responde à pergunta dizendo que o interesse dessa matéria cromática procede do fato de ser merda... Pinta o artista com matéria fecal ou é esta a que curiosamente aparece em sua obra com independência de Miró?

Deixemos momentaneamente este assunto. Se, por um lado, algumas idéias mironianas não têm sido levadas em conta, por outro, outras foram adotadas pela crítica e pelo público em geral como algo representativo e, amiúde, colocadas fora de contexto. Tal atitude conferiu-lhes uma falsa singularidade ou as converteu em algo mais do que simples frases. Assim, "temos de assassinar a pintura", por exemplo, é uma expressão mironiana que, pelo fato de ser repetida

1. Embora de maneira breve, tenho me ocupado desta questão em diferentes trabalhos: Salabert (1985, p. 231), (1987, pp. 3-9), (1989, pp. 345-356) e (1994, pp. 44-45). 
com freqüência e ser proveniente do pintor, fez com que Jean Paul Sartre pensasse que se tratava de um quadro e não de uma opinião formulada numa frase... E mesmo não tendo visto a "obra", Sartre, em 1946, se refere a ela por escrito como se fosse um quadro conhecido... Anedotas como esta são ilustrativas, mas também dão margem a uma micromitologia para turistas da reflexão estética. Isso de que a pintura deva ser assassinada, não nos faz cogitar sobre uma possível relação entre o curioso afeto mironiano pela Matéria e o desejo vanguardista de liquidar a tradição? Na verdade, a pintura não deve ser assassinada porque seja algo de que nos convenha prescindir - como quem diz "vai à merda!" diante de alguma coisa que não lhe agrada (uma expressão como essa é usada por Toulouse-Lautrec para se referir ao ofício de pintor) -. Ao contrário, para Miró somente uma pintura "inaugural", feita de excrementos e, portanto, capaz de rematerializar o mundo, possui a presença semântica necessária para romper com a tradição, para ir além de si mesma... e recuperar uma origem. Não damos relevância à afirmação de Leonardo acerca de que a pintura é "coisa mental", como se em seu momento histórico isso tivesse sido algo excepcional, profético para a arte contemporânea, quando na realidade é o contrário? Em contrapartida, fazemos questão de ignorar aquela outra observação com a qual esse mesmo artista, ao nos indicar que cada pintor "se pinta" expressa uma opinião comum para a época. Seria mais conveniente que nos ocupássemos deste moderníssimo "pintar-se a si mesmo", porque, com isso, talvez nos fosse possível compreender que a cena pictórica mironiana é uma contínua e direta teatralização do corpo: desde os signos mais elaborados, relativos à anatomia, até a aniquilação de seu sentido - e, por conseguinte, de qualquer processo semiótico - mediante a mais pura função fisiológica consistente em defecar. Não é tarefa do artista representar a origem romanticamente: seu dever é atingi-la. Nessa perspectiva, Miró é relativamente a Goya o que Goya foi - numa larga escala - a Rubens ou a Velázquez e, Velázquez ao maestro de Taüll, e este ao desconhecido pintor de Altamira, ao de Lascaux ou a qualquer outro muito mais distante ainda. Porque, ao final de contas, 
dorsal do acaso generalizado, como uma repulsa, a recepção do inesperado e desagradável. Cabe acrescentar unicamente que os dois primeiros modelos do excremento, o ubuesco e o plástico, são os mais importantes, principalmente porque podemos relacioná-los mais diretamente com a atividade criativa de Miró. Falaremos ordenadamente de tudo isto.

\section{A merda Ubuesca e o retorno do espírito à matéria}

O fantoche teatral Ubu entra em cena por primeira vez em 1888 com a obra Ubu roi, de Alfred Jarry. E, logo que entra, sua primeira ação é jogar na cara dos espectadores o que será seu grito de guerra: "Merdre"! E o público se indigna. A partir daí a atividade da personagem é um contínuo insulto ao comedimento e à razão.

Concebida a obra para marionetes, Jarry tinha imaginado no Père Ubu um indivíduo carente de nobreza que estaria além do grotesco, uma personifica-

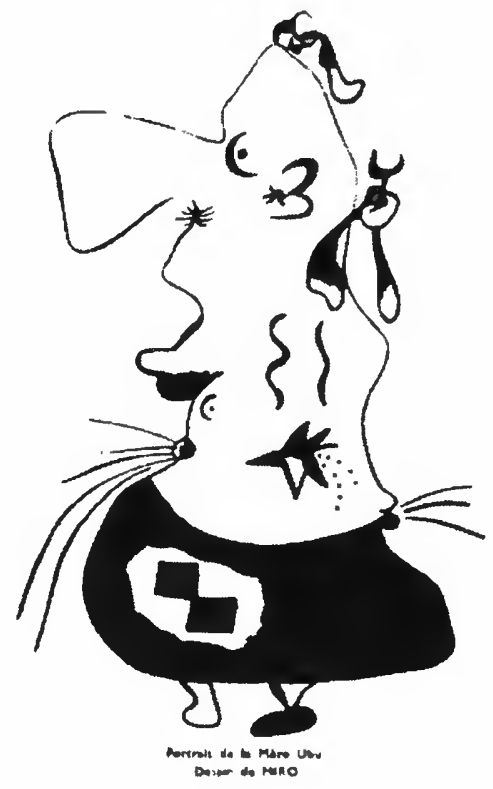
ção vagamente antropomorfa liberada da força, um paradigma do ser humano submetido a suas funções instintivas mais imediatas ${ }^{3}$. Com uma mentalidade estomacal, atropela quando avança, devora quando come, acumula para possuir... Alheio a qualquer consideração pelas pessoas ou as coisas, as presença física de Ubu adquire um caráter inevitável de hecatombe de acordo com o sentido etimológico do termo: cem bois arrasam ao passar tudo quanto encontram. Quando a linguagem Ubuesca não se limita a renegar,

3. Com posterioridade à redação deste trabalho, Presses Universitaires de France (PUF) publicou a divertida obra de Daniel Accursi intitulada Merdre, obra em que seu autor associa a "merdre" - não precisamente o excremento em geral, mas - que aqui chamo merda ubuesca - com a vida e a criação, para transmitir a embriaquez de que nos fala Nietsche como única forma de exaltação da vida verdadeira: "La Merdre não é a pergunta sem resposta. Ao contrário, é a resposta sem pergunta." (Accursi, 2000:10 s). 
suas flores mais preciosas se abrem na ordem do impropério. Nada escapa da sua ação. A exclamação que profere - Merdre! - é uma distorção de merde, como se Jarry tivesse querido acrescentar esse " $r$ " aumentativo, hiperbólico - quiçá de uma imprudência premeditada - ao mau cheiro literário, ao fedor que se espalha ao se repetir a palavra invadindo o espectador. Assim como merdre remete ao excremento, cornegidouille, outro dos seus termos, se reporta, por sua vez, à pança. Portanto, ambos se convertem em signos da personalidade ubuesca e de seu procedimento mais primário submetido à pulsão: ingerir, digerir, excretar.

Desprendido de tudo, despidas as paixões de aparência e pensamento, Alain dizia que em Ubu somente temos a força bruta: o que reina em cena está por debaixo do pior. Jarry inclusive tinha desenhado sua personagem. Teve a idéia de representá-la como uma marionete de luvas com uma longa túnica que lhe chegava até os pés e uma cabeça encapuchada, comprida e pontiaguda. Sob o braço, o bastão canônico de Guignol para o ataque e a defesa. Sobre a barriga - a enorme e extremamente vulgar gidouille francesa -, uma linha espiral com a corda de um velho despertador indica, provavelmente, o lugar central e único das percepções de Ubu: todo processo sensível ligado ao estômago.

O interesse de Miró pela corrosiva comédia de Jarry vem de longe. A exclamação e sua atitude global são para ele um topos cultural, uma referência persistente. Mas de duplo valor. Porque, além do anedótico, Ubu é um signo negativo da irracionalidade em geral e da cegueira política em particular: destruir para medrar e medrar destruindo lhe sugerem, sem dúvida, a incompreensível circularidade implícita num procedimento desumanizado que, à maneira de um inseto que gira em torno da chama que o aniquilará, tem seu único centro no nada. Mas, às vezes, o grito merda! É o termo de uma oposição - melhor dizendo, de um rechaço - que, dependendo de seu objeto, se faz merecedor de um valor que, então, se torna positivo. Ubu joga sua merda sobre tudo quanto se opõe ao seu avanço para destruí-lo. Miró, ao falar, exatamente isso sobre tudo quanto ao seu entender se opõe hipocritamente, em nome de falsos ideais, à razão comum. Se, de um lado, a merda é signo 
da destruição, de outro, é um exorcismo. Mais adiante retornarei ao assunto.

Por enquanto, o decorado de fundo é esse. E assim como, em 1935, Miró tinha pintado uma estranha premonição de nossa catástrofe bélica em seu Hombre y mujer ante um montón de excrementos (Homem e Mulher diante de um monte de excrementos) - no horizonte de uma cena desolada, o "monte" a que alude o título destaca como um incomum monumento-, em 1973 e 1974, pinta formas semi-humanas em série. Mas nesse momento não só terá desaparecido aquela fosforescência onírica presente em Hombre y Mujer (Homem e Mulher), mas, em vários casos, o cromatismo se limita, ademais, a uma grande extensão da cor negra. Nalgum quadro, a "figura" é uma forma globular ou, de acordo com a maneira de olhar, uma montanha de sombra. Mujer cara al sol (Mulher defronte ao sol), de 1974, é a silhueta quase sem forma de uma personagem inquietante com uma cabeça pontiaguda que lembra os desenhos jarrynianos de Ubu. Reconhecemos mais amiúde essa presença graças a um olho ensangüentado que fura o negror de pinceladas e borrifos como uma ferida que nos vigia, um buraco que goteja espreitando o espectador... Pouco importa que Miró tenha dado a essas silhuetas uns títulos, digamos, aleatórios, extremamente genéricos ou vagamente significvativos: Personaje (Personagem) (1973), Personaje, pájaro (Personagem, pássaro) (1973), Cabeza (Cabeça), de1940-1974, Cabeza I e Cabeza II, de 1974, etc. Pouco importa, repito, porque já em Mujer cara al sol o termo "mulher" apenas nos distrai no tocante à relação do ditador Franco com o Ubu de Jarry sugerida por essa matéria imunda que avança encobrindo como uma maré o espaço do quadro...

Evidentemente que as personagens desses anos exigem uma análise intertextual. E é então quando, no nível mais simples, aparecem como um ponto de confluência de dois textos precedentes, um literário e outro político: o fantoche de Jarry, de um lado, as trevas da Espanha franquista, de outro. Ubu transmutou-se, para Miró, no general Franco e este em modelo de irracionaldidade. E se o monte de excrementos era o único objeto perceptível no horizonte do homem e da mulher de 1935, agora, enquanto a merda resume a política de 
força que imperava no país, uma vez convertida em exclamação merda! - afasta tudo quanto foi anterior do horizonte do artista. A "mulher" do quadro de 1974, essa forma que olha na direção de um sol banhado pela escuridão, que é senão uma Espanha "cara al sol" ("defronte ao

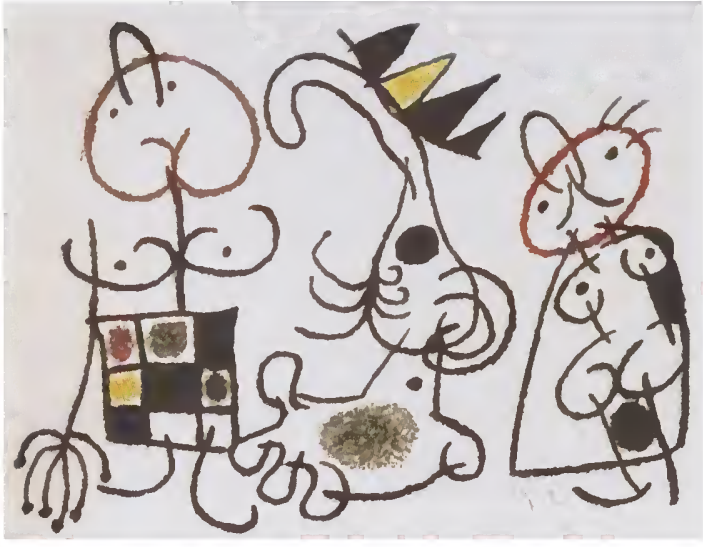
sol") ${ }^{4} \ldots$

Assim, enquanto na perspectiva mironiana a merda Ubuesca funciona como bandeira da figura do ditador, a política franquista é um disfarce da razão semelhante ao instinto irracional daquele outro fantoche sanguinário. O que importa é que a personagem de Jarry, transmutada dessa maneira, constitui um exemplo plástico de violência irracional e as obras mironianas se convertem num signo do mal projetando o conteúdo semântico do original dramático muito mais longe do que talvez ele mesmo podia fazê-lo.

Para onde nos conduz tudo isto? Para o trabalho mais interessante de Miró no teatro. Refiro-me à sua colaboração com o Teatre de la Claca a partir de 1975 e ao espetáculo final: Mori el Merma. Miró aí não quer unicamente "que o espetáculo seja a festa da celebração da Morte de Franco", defende também o propósito de que esse mesmo espetáculo "tem de causar o estranheza de um sonho" (Baixas, 199, p. 431). A partir desse instante o Ubu-Franco é sucedido pelo Merma $^{5}$. Por acaso não se trata do inconsciente - o Id freudiano, Das Es - num cenário de sangue e merda, denúncia da opressão franquista na Espanha?

4. Nota do tradutor. "Cara al sol" significa, literalmente, defronte ao sol, mas é preciso observar que, no caso, o autor utiliza essa expressão também com o sentido que ela tem como título e parte da letra de uma canção muito popular entre grupos fanáticos partidários de Franco.

5. Nota do tradutor. O termo catalão "merma" tem vários significados pejorativos e poderia ser traduzido por chato, insuportável, paspalhão.... Nesse contexto, acreditamos que Morri el Merma, considerando suas conotações políticas também, significaria Morra o Espantalho. 
Disse que a merda Ubuesca era qualitativa, passível de relação com um certo imediatismo. A "Merdre!" de um Ubu primário passa de Jarry a Miró como um signo elaborado da revolta. O fantoche, para seu autor, era um signo de desprezo; em Miró será a monstruosidade em ativo, a antibeleza dinamizada no teatro, a força telúrica grotescamente orientada na direção do mal.

A documentação gráfica feita por Catalã-Roca sobre o artista enquanto pintava as personagens de Mori el Merma é bastante explícita. Miró aí não pinta, borrifa, suja e tornar a sujar, projeta a pintura sobre a vestimenta das personagens, aconselhando que elas se movimentem de maneira irracional, como os animais. $\mathrm{O}$ negro é básico porque a ausência de cor é uma falta de luz cujo valor simbólico não precisa ser exposto. Também o texto de Joan Baixas (ibid.), "Nedar contra corrent fa bíceps" ("Nadar contra a corrente desenvolve os músculos"), é explícito, pois transcreve as ocorrências de Miró durante o espetáculo: "O argumento me é indiferente... Participarei plasticamente e basta". O quê dizer carece de importância frente ao como. E bem, como conseguir que a plástica não signifique mais uma vez a mítica transfiguração da

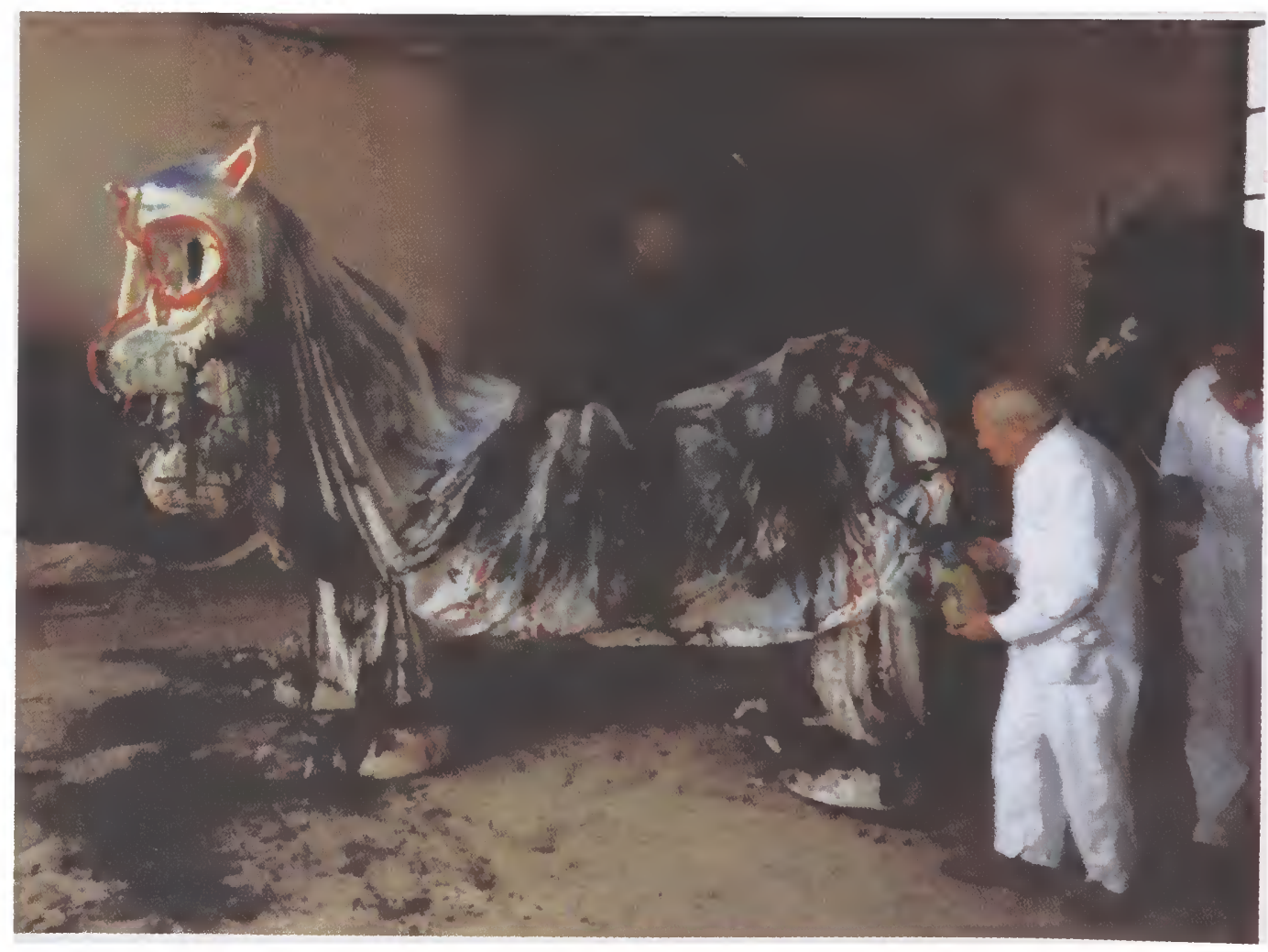

$\overline{\text { Significação } 20 \cdot 178}$ 

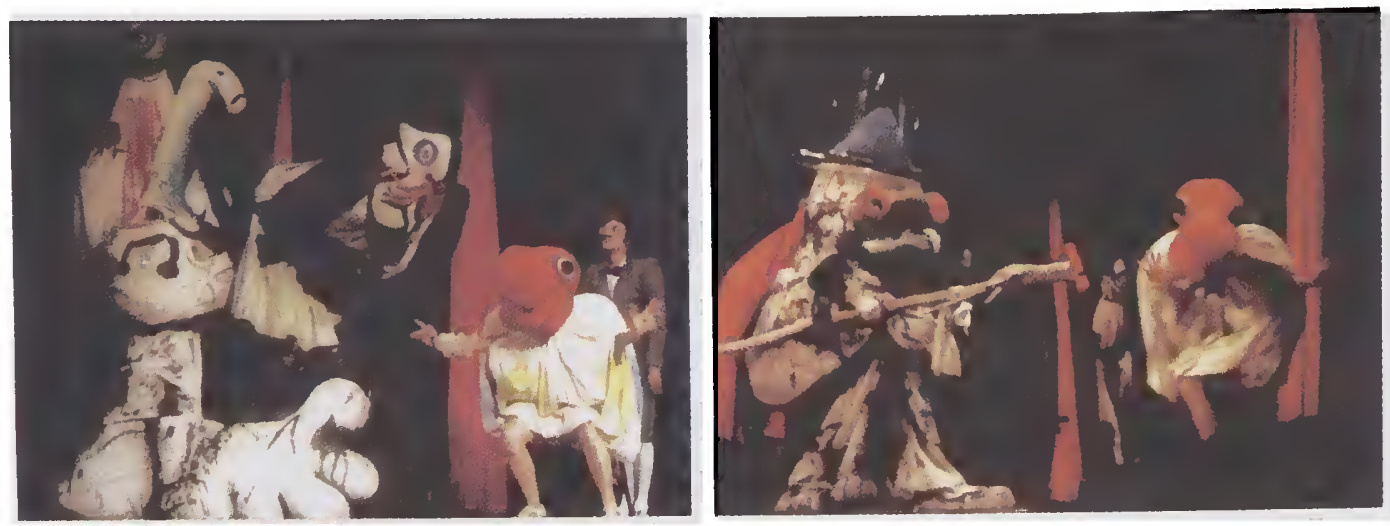

matéria pelo espírito? Como conseguir, pintando, precisamente o contrário? Entenda-se que o contrário é o retorno do espírito à matéria que é sua origem. Em suma, como se adentrar no caminho da criação seguindo uma direção oposta à que a história nos tem ensinado? Porque a pintura não só suja. A própria forma pictórica procede da imundícia.

Trabalhando, pois, para Mori el Merma, dir-se-ia que Miró preserva e guarda, como se recolhesse e mimasse cada gotejamento. $\mathrm{O}$ artista não pinta sobre os trajes para o espetáculo o sobre a lona que estendeu no chão e sobre a qual trabalha. Literalmente falando, coleciona borrifos, derramamentos e jactos. E, enquanto faz tudo isso, o que mais faz? De vem em vez urina nela. Por quê? Porque amassar as formas do visível com o que o corpo excreta equivale a devolver a devolver à terra o que é dela. É a isso que me refiro quando afirmo que a merda de Ubu é para Miró, em primeira instância, qualitativa; pelo seu imediatismo fisiológico. Não é uma simples questão de coprofilia, mas de retorno simbólico a uma origem isenta de sentido.

\section{A merda plástica e a forma da beleza}

Sobre essa lona que utilizará depois como suporte de novos quadros, ele, por enquanto, urina. Baixas, que acompanha o artista, observa que lá pequenos signos desenhados, as pegadas dos emplastros de terra, e ele (Miró) repete que se é necessário poderá urinar ainda mais. E para que eu acredite nisso ele faz com que eu urine e eu urino. (1994, p. 232). Miró não só 
faz isso, mas convida os outros para que o façam também. Urinar sobre o quadro é como defecar nele: equivale a por a alma na pintura, a dar-lhe um corpo espiritual a cada forma.

O excremento de inspiração ubuesca é qualitativo, como já disse. Mas este que temos agora ultrapassa a qualidade para entrar no espaço do quantitativo, isto é, no espaço efetivo e bem real. Em duas etapas, porém. Uma, que poderíamos de transição - em parte quantitativa e em parte simbólica -, é a representação do ato defecação; outra, a apresentação da merda em sua literalidade. Temos feito referência ao quadro Hombre y mujer ante um montón de excrementos, de 1935. É a primeira etapa. Mas em La Masía ("A chácara"), de 1921-1922, Roberth Hugues já tinha detectado a presença de uma estranha personagem cuja posição sugere a do caganer (é dizer, o cagão) (veja-se Vallès, 1992, 1994). O caganer $^{6}$ é essa figura de presença inevitável no presépio catalão e cuja única função na cena consiste, ao que parece, em defecar tranqüilamente ${ }^{7}$. Mas esse caganer com os braços levantados, como em cruz, adota em La Masía uma posição que sugere tanto a forma dos siurells majorquinos ${ }^{8}$ - figurinhas de terra cozida que representam homens ou animais com grandes chifres - quanto a do crucificado. Ambas coisas, siurells ou crucificado - a cruz antropomorfa, enfim -, são signo de "origem" e, ao mesmo tempo, sinal de território.

6. Observação do tradutor. Caganer é um vocábulo do catalão que o autor utiliza e que particulariza bem os sentidos conotados atribuídos à defecação.

7. Um "caganer" ainda mais explícito aparece no desenho de Rembrandt intitulado Sátira da crítica de arte (Metropotian Musem of Art, New York). A personagem de perfil, à direita da composição, representaria, segundo a interpretação de Schneider (1993, p. 286), o próprio Rembrandt defecando sobre seus críticos - uma versão "merda por merda" da lei de Talião - por terem estes comparado sua pintura com o estercol.

8. Observação do tradutor. Siurell é uma figurinha de cerâmica típica da ilha de Majorca e que pode representar uma personagem montada num cavalo ou um pássaro, por exemplo. 
Lá, plantado no centro da composição, o caganer de La Masía alude provavelmente a uma tomada de consciência de identidade do individuo graças a esse donativo que ele mesmo faz à terra que lhe dá vida, adubando-a, fecundando-a com seu excremento. A adesão mironiana à terra é demasiado conhecida e por isso não vamos alongar o assunto.

Existe, porém, algo mais. Por acaso a figura do caganer não está no centro do quadro? Não marca na composição um ponto nuclear que a perspectiva deslocada do conjunto não consegue assinalar? O caganer não é o centro geométrico do quadro: é seu centro afetivo. Falando do Dilúvio de Ucello, por exemplo, quando Schefer se refere ao ponto focal da cena lhe dá o nome de ponto "fecal" Eis que a resposta à focalização abstrata da perspectiva racional é uma fecalina figurativa de conteúdo emocional.

Vejamos agora a segunda etapa. O qualitativo, de fato, interessa pouco ao proceder científico. Seu quinhão é a quantidade: ao menos com isso se demarca um domínio. Não se trata, por enquanto, de uma merda literária, não é ainda o excremento simbólico. Mas também não é uma expressão vulgar ou um tique lingüístico na exclamação que invoca essa substância. Já fizemos menção às conversações de Raillard com Miró no atelier deste último em Majorca. Repetimos: lá Raillard observa, pergunta, comenta. Miró, nesse ínterim, se movimenta através de restos de diversa procedência, coisas heteróclitas, inspeciona e manipula. E, num dado momento, relata Raillard (1987, p. 186), o artista tira daquele monte de coisas um cartão nojento, roído por todas partes, cheio de urina e excremento, quase transparente, a relíquia de um cataclismo, o nada. Então, o entrevistador percebe algo que não carece de importância. Nota que o artista não vê o conteúdo das coisas, que não busca nenhuma transcendência espiritual que possa iluminá-lo com uma idéia... Claro, porque isso seria traduzir, inverter em outra parte da rotunda realidade do cartão, dos pregos oxidados, de uma madeira carcomida, de uma embalagem... A atenção de Miró quando observa qualquer objeto ou resíduo de coisa é "restrita",e portanto, um pouco selvagem, à própria matéria, sem ir além da própria textualidade. 
Sua catalanidade 9 se mostra nessa adesão à terra: "ao pão, pão, e ao vinho, vinho" Também é conveniente nomear a matéria com seu próprio nome: não é nem isto nem aquilo, senão matéria. "Eu não faço a tradução de nada", exclama; existe uma força magnética, uma força... (e chegando a esse ponto, o discurso de Miró devém invariavelmente onomatopéia), uma força que clac! Sempre esse clac! Não uma idéia que procura realização, não uma inspiração súbita, mas a expressão do choque, do impacto, melhor dizendo, da eclosão de uma matéria cujo dinamismo faz com que ela emirja ganhando forma.

O cartão, conforme ao que nos foi dito, é nojento, cheio de urina e excremento. No entanto, antes foi vista uma obra relativamente insólita, talvez inacabada: três folhas amareladas pelo esmeril, uma ao lado de outra, machadas da matéria de uma cor marrom "excepcional" E Raillard, curioso, pergunta ao artista se ele obteve essa cor "acrescentando o amarelo. Haverá outras manchas marrons como essa?" Miró responde que talvez não, que essa matéria tão bela a obteve cagando nela...

Não nos diz ele mesmo que sua única intenção é retornar à fontes? A merda de Miró não é uma merda por numa lata de conserva selada, uma substância literária e virtual que não podemos ver. Manzoni com a sua nos oferece um pacote cultural hipersimbólico. Miró, em contrapartida, nos oferece uma matéria natural, extra-semiótica. Efetivamente, "Eu não faço tradução de nada!" A substância "excepcional" mironiana - diferente à de Manzoni - não é uma piada, nada tem de calembour de artista. A merda depositada em seu suporte pictórico é o limite da Matéria que, em sua radical escuridão, retorna à espiritualidade. Já sabemos que o criador neoplatônico busca, através de caminho da Luz, o mais para lá da forma completa. Mas é necessário considerar a mesma vereda em direção contrária. Miró busca o mais para cá da forma, deseja, através do caminho das trevas, chegar até uma protoforma. Insistimos e repitimos:

9. Observação do tradutor. Entenda-se nesse termo um significado que se reporta a tudo quanto seja especificamente catalão, traço da singularidade cultural da Catalunha, assim como brasilidade remete aos traços do que se considera atinente ao Brasil e a suas singularidades.

$\overline{\text { Significação } 20 \cdot 182}$ 
não existe espírito algum (primeiro) depositando-se formalmente (depois) na matéria. Essa seria a tese winckelmanniana. É a própria matéria, a que fica debaixo, aquela que ganha forma primeiro para espiritualizar-se depois.

Sabe-se que as fontes neoplatônicas da beleza - Plotino, por exemplo - jaziam na forma imaterial, na luz inefável e, nesse domínio, na "idéia" que o artista possuía graças a uma intuição superior. Mais de um milênio depois, "dalle più alte stelle/discendo uno splandore" ("das estrelas mais altas/ descendo um esplendor"), cantava num dos seus sonetos Michelangelo. Ao ser depositário do esplendor ultramundano, entendemos que a mão do artista deva obedecer ao intelecto ("la man che ubbidisce all'inteletto"). A mão é serva e o intelecto reitor. Embora não seja assim para Aristóteles. Para ele a forma é um efeito sensível dum dinamismo material. A physis é automotriz, o movimento se manifesta no tempo mediante formas. É claro que Michelangelo era de opinião de que, na matéria, há uma

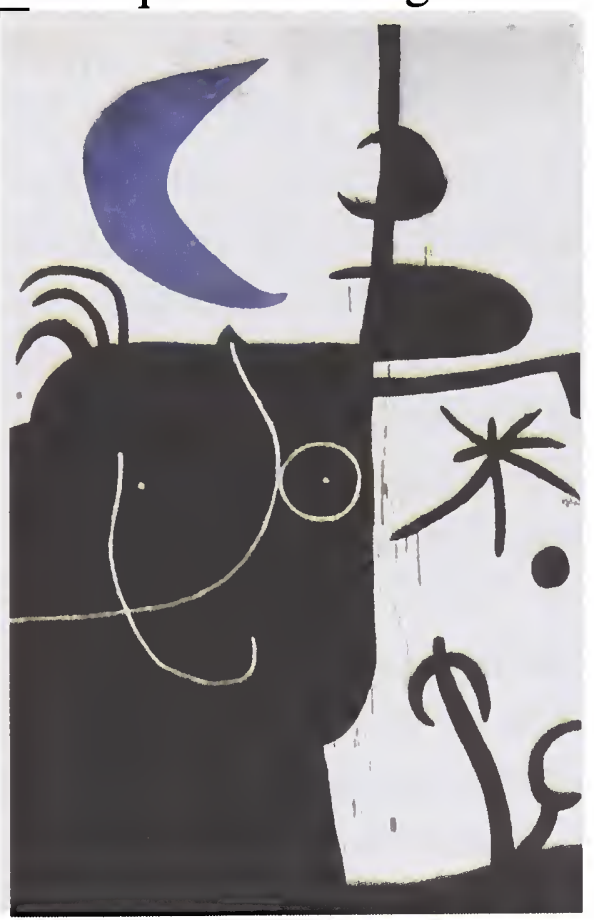
forma e de que esta tem também sua potencialidade formal. E isso resulta mais interessante. De modo que a matéria renascentista não parece totalmente inerte, possui uma vida que não procede - pelo menos em razão da intervenção do artista que a configura das estrelas. Será necessário retornar a dizer agora o que, tendo em vista nosso propósito, significa tudo isso? Significa que, quando Miró fala de "assassinar a pintura", alude, em realidade, ao reverso da tradição pictórica que tinha entendido o problema da representação como caminho no rumo da luz imaterial, como um desejo de transcendência da forma temporal na eternidade.

Entretanto, as vanguardas do século passado mandaram à "merda"! tudo isso. E também Miró diz "merda"! A pintura tem de voltar à sua verdadeira origem na Natureza, à matéria corruptível. 
Em virtude disso, existe uma contemporaneidade artística na physis aristotélica manipulada. A pintura da pulsão se espalha com Pollock, artista que soube praticá-la através dos jatos de tinta. Com Miró foi a terra e foram os borrifos. O sujo de urina e o cagado. E, em continuação, a carne.

Terra ou merda, carne. A corrupção fala da vida e a vida se anuncia a través da putrefação. $O$ resto é sofisticação cultural (o que é a tópica corrupção moral contemporânea senão uma metáfora cultural viável da putrefação da matéria?). A pintura assassinada por Miró e por outros que com ele se assemelham reencontra agora a sua interioridade, mas outra: a verdadeira e sem idéias preconcebidas.

\section{A merda exclamativa: o rechaço e a boa sorte}

A mão mironiana que surpreende quando atua é e não é aquela outra mão que surpreendeu Paul Valéry. $O$ poeta francês ficava perplexo diante dessa parte da anatomia, mas se a sua surpresa é metafísica, a de Miró é física. Para o trabalho, a mão de Miró é o lugar onde o corpo desemboca e o corpo é o que vive, se movimenta e transforma a matéria num ciclo interminável de ingestão e excreção. Se o pintor se pinta a si mesmo, como dizia Leonardo, hoje teríamos de acrescer a isso que o pintor estigmatiza o suporte e nele se estampa: deposita seus vestígios, deixa seu rastro. Parece-se àquele artista chinês que começa seu trabalho enfiando a cabeça num balde de tinta para utilizar depois sua cabeleira como pincel sobre $o$ papel.

Também Miró se suja assim, quero dizer literalmente. Na época de Hombre y mujer ante um montón de excrementos (1935), diz que "então me obcecavam umas palavras de Rembrandt: Onde encontro rubis e esmeraldas é num monte de excrementos." (Permanyer, 1979, p. 122). Depois de ter abandonado a natureza, a arte prossegue a sua aventura retornando a ela: é a physis. Por ventura Platão não tinha buscado a idéia ultramundana além das formas sensíveis, mediante a filosofia, a reminiscência, o amor, o êxtase?... Também poderia ter dito que como o artista "não tem (nem) idéia" - da beleza, entende-se - será conveniente que, ao abandonar 


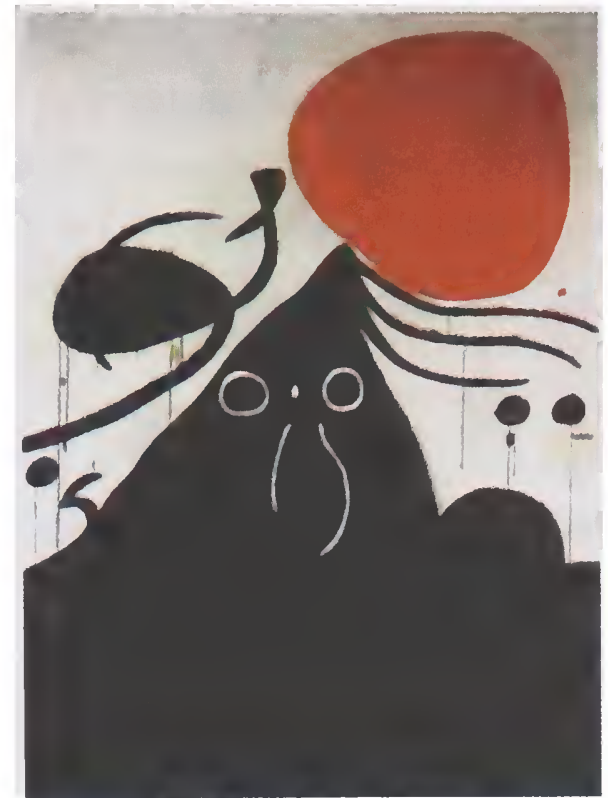

ra sarcástica do sublime.

as formas sensíveis, se ocupe da verdade (o que, evidentemente, é outra idéia...). Mais positivo é Aristóteles: ele se contenta com a forma material dinâmica, forma na que vê uma ordem estruturada que será a beleza artística. E Miró ainda deseja ir mais longe. Ele que a matéria sem forma... Mas, ao final de contas, o que é a matéria sem forma? É o eixo de um romantismo invertido. Quero dizer que o sem forma, enquanto categoria oposta ao formal - signo do belo - é a caricatu-

Como já tenho sugerido, a merda exclamativa de Miró é a merdre de Ubu devolvida ao seu lugar coloquial de origem. É aquela merde! Francesa que delata a surpresa, mas que também deseja boa sorte. Ao mesmo tempo que fala de nosso cotidiano assombro diante do que não esperávamos, expressa nossa esperança de que algo melhor aparecerá no horizonte dos nossos acontecimentos. Exorciza e traz boa sorte. Primeiro é sombra da vida, pelo menos porque quando esta acaba ela é tudo quanto nos resta: o signo familiar do que esteve aí presente. $\mathrm{E}$, segundo, porque a terra adubada com merda é terra fecunda, a que produz e dá vida. (Laporte, 1980). É o adubo necessário sem o qual, esgotado o solo, não dá frutos. A vida procede da fermentação e da podridão. Excremento está em toda parte, antes e depois do que é vivo. A vida remete a um antes de si mesma povoado de matéria excrementícia, uma substância geratriz e no tocante ao seu depois nos diz que ainda haverá mais.

Por isso, a merda exclamativa já entra de cheio na categoria do simbólico. Não é exclusivamente qualitativa nem unicamente quantitativa, nem imediata nem efetivamente real, mas ambas coisas ao mesmo tempo. É a instância que regula as outras duas. "O senhor dizia que ao morrer diria merda", pergunta o crítico entrevistador. $\mathrm{E}$ Miró responde que sim, efetivamente: "Merda para toda a sociedade". E para que fica claro repete: "Merda para toda a sociedade, 
merda para tudo o que não tem importância”. (Raillard, 1978, p. 132). Isso de negar a importância - disto ou daquilo - poderia ter sido poupado. É um tique lingüístico que o obriga a misturar a ignóbil matéria fecal, lugar de um exílio para quem perde as formas - "Vai à merda"!, dizemos -, com a merda francesa cheia de virtudes - "Je te dis merde!", dizem eles e nós agradecemos a intenção porque nos desejam um horizonte de plenitude.

Com isto já é suficiente. Fazer história, seja da pintura ou da arte em geral, equivale a fazer um repasse de seus mitos. E, precisamente porque os mitos que alimentam o mundo da cultura resistem à história, a arte moderna conseguiu ser "de rompimento"10, original, surpreendente, porque valendo-se de mitos que não esperávamos nos libertou de outros mais velhos que tínhamos assimilado até o ponto de acreditar que eles eram naturais. Sabemos a resposta e, mesmo assim, perguntamos: quem disse que a arte e a beleza andam juntas, inclusive que são sinônimos, e que a Beleza deve ser higiênica, desmaterializada, inodora, esmagando ao mesmo tempo a Arte com o peso de uma eternidade atribuída? Porque desvirtuar com semelhantes obrigações uma das formas mais felizes - e também fugazes - da liberdade humana?

10. Observação do tradutor. O autor utiliza o termo "rupturista", isto é, aquilo que causa rupturas e essa é o significado que queremos manter em rompedora. 


\section{Bibliografia}

ACCURSII, D. 2000. Merdre. Paris.

BAIXAS, J. 1994. Nedar contra corrent fa bíceps, Miró en escena. Barcelona: Fundació Miró.

GREIMAS, A. J.; COURTÉS, J. 1993. Sémiotique. Dictionnaire raisonné de la théorie du langage. Paris.

LAPORTE, D. 1980. Historia de la Mierda. Valencia.

PERMANYER, L. 1978. Revelaciones de J. Miró sobre su obra. Barcelona: Gaceta Ilustrada.

RAILLARD, G. 1978. Conversaciones con Miró. Barcelona.

SALABERT, P. 1985. (D)efecto de la pintura. Barcelona. Reus. 1987. El no-saber en Pintura. Materia, però fecal. Tascó 8. 1989. The signifier in painting, shit. Semiotica 81-3/4. 1994. Cuerpos pintados y episodios de la carne. Arte Internacional 19, Bogotá. . 2003. Pintura anémica, cuerpo suculento. Barcelona: Laertes.

SCHEFER, J.-L.1976. Le Déluge, la peste. Paris: Paolo Uccello.

SCHNEIDER ADAMS, L. 1993. Arte y psicoanálisis. Madrid.

VALERY, P. 1941. Tel quel I. Paris.

VALLÈS, I. 1992. Reflexió, a manera de pròleg, entorn d'un ritual perenne, El caganer, Barcelona. . 1994. Joan Miró: el "caganer astral” Caganòfil 5, Barcelona. 